\title{
Developing medical professionalism in future doctors: a systematic review
}

\author{
Vimmi Passi, Manjo Doug, Ed Peile, Jill Thistlethwaite, Neil Johnson \\ Warwick Medical School, University of Warwick, UK \\ Correspondence: Vimmi Passi, Warwick Medical School, University of Warwick, UK \\ Email: vimmi.passi@warwick.ac.uk \\ Accepted: April 30, 2010
}

\begin{abstract}
Objectives: There are currently no guidelines on the most effective ways of supporting medical students to develop high standards of medical professionalism. The aim of this review is to summarise the evidence currently available on methods used by medical schools to promote medical professionalism.

Methods: We performed a systematic search of electronic databases (Medline, PsychInfo, British Education Index, Educational Resources Information Centre, Sociological Abstracts and Topics in Medical Education) from January 1998 to October 2008. Outcomes studied were methods used to support and promote the development of professionalism in medical students.
\end{abstract}

Results: We identified 134 papers and five main themes for supporting the development of professionalism in medical students: curriculum design, student selection, teaching and learning methods, role modelling and assessment methods. However, the level of empirical evidence supporting each of these methods is limited.

Conclusions: Identification of these five areas helps medical schools to focus the emphasis of their approaches to developing professionalism and identifies future research areas. This review offers a preliminary guide to future discovery and progress in the area of medical professionalism.

Keywords: Professionalism, medical students, curriculum, teaching, assessment, role modelling

\section{Introduction}

Medical professionalism forms the basis of the contract between doctors and society and it is thus imperative that professionalism is incorporated into the undergraduate curriculum. ${ }^{1,2}$ The importance of teaching medical professionalism has been emphasised in many countries worldwide. However, at present there are no guidelines on how professionalism should be developed in medical students.

A Lancet review in 2001 emphasised the importance of a commitment to the teaching of professionalism to medical students and suggested that rigorous research was required in this area. ${ }^{3}$ Although recent literature has highlighted the continuing challenges of educating for medical professionalism over the past seven years; the literature on professionalism has grown exponentially. This expansion in the literature, taken together with the priority that the teaching and assessment of professionalism has assumed for medical schools worldwide, means that we can begin to make recommendations on the most effective methods for medical schools. The aim of this systematic review is to evaluate the evidence supporting the development of professionalism in medical students. A summary of the key methods used to support the development of professionalism is presented. However, first it is necessary to review briefly the key definitions of medical professionalism in use, as the clear specification of the curriculum is highly dependent on these.

\section{Defining medical professionalism}

There are numerous definitions of medical professionalism provided by major medical organisations. International experts in North America and Europe have been instrumental in defining professionalism. The General Medical Council's publication Good Medical Practice describes the duties of a doctor as 'providing good clinical care, maintaining good medical practice, teaching and training, relationships with patients, working with colleagues, probity and health'. ${ }^{4}$ In the UK, the General Medical Council guidance to medical schools on change in the undergraduate curricu- 
lum, Tomorrow's Doctors, has been influential to the teaching of professionalism emphasising the attitudes and behaviour. ${ }^{5}$

The American Board of Internal Medicine (ABIM) commissioned Project Professionalism, which sought to define the components of medical professionalism. ${ }^{6}$ Professionalism as defined by the ABIM, has six components: altruism, accountability, excellence, duty, honour/integrity and respect. Similarly, CANMEDS a project of the Royal College of Physicians and Surgeons of Canada, delineated a competency framework and specifies seven roles expected of the competent specialist: medical expert, communicator, collaborator, manager, health advocate, scholar and profesional. $^{7}$

In 2002, a combined North American and European Internal Medicine Boards project published the Physician's Charter - a declaration on medical professionalism requirements for the new millennium. ${ }^{8}$ It has subsequently been endorsed by over 120 medical organisations and translated into ten languages. The Physician's Charter consists of three fundamental principles (patient welfare; patient autonomy and social justice) and a set of ten professional responsibilities (commitment to competence, honesty, confidentiality, relationships, quality of care, access to care, distribution of finite resources, scientific knowledge, managing conflicts, responsibilities). ${ }^{8}$

Most recently, the Royal College of Physicians of London's Working Party on Medical Professionalism has defined medical professionalism succinctly as 'a set of values, behaviours and relationships that underpin the trust the public has in doctors, with doctors being committed to integrity, compassion, altruism, continuous improvement, excellence and teamwork'. ${ }^{9}$

It is however, important to emphasize that there still remains uncertainty about what professionalism actually is and although medical educators primarily frame professionalism as a list of characteristics or behaviours, many sociologists favour theories that incorporate political, economic and social dimensions into the understanding of the nature and function of professionalism. ${ }^{10}$ In addition, moralists will argue that professionalism should be seen clearly as an aspect of personal identity and character which develops over time. ${ }^{11}$ Finally, many authors have moved the focus from the individual to the institution and have argued that professionalism should be inculcated within medical schools with complete integration of a culture of professionalism involving staff, faculty, residents and students. ${ }^{12-14}$

\section{Methods}

\section{Search strategy and selection criteria}

We systematically searched the following six electronic databases: Medline; PsychINFO; EMBASE; Educational Resources Information Centre (ERIC); Sociological Abstracts; and Topics in Medical Education (TIMELIT) from
1998 to October 2008. Only those articles that had abstracts available in English were included and we limited the retrieved articles to the past ten years on the basis that a major review on this subject had been published in 2001 and we wished to focus particularly on progress in this field since that time. ${ }^{3}$ Medical subject headings (MESH) and key words included were: "medical education;" combinations of "professionalism;" "professional behaviour/practice;" "medical students;" and "undergraduate medical students" (Table 1).

Table 1. The inclusion and exclusion criteria for the systematic review

\begin{tabular}{|c|c|c|}
\hline & Inclusion Criteria & Exclusion Criteria \\
\hline 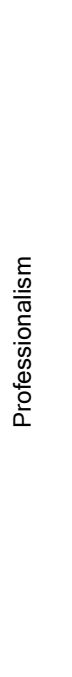 & $\begin{array}{l}\text { Defined by the RCP as: } \\
\text { Medicine is a vocation in which a doctor's } \\
\text { knowledge, clinical skills and judgment are } \\
\text { put in the service of protecting and restoring } \\
\text { human well being. This purpose is realised } \\
\text { through a partnership between patient and } \\
\text { doctor, one based on mutual respect, } \\
\text { individual responsibility and appropriate } \\
\text { accountability. } \\
\text { Doctors are committed to: } \\
\text { - Integrity } \\
\text { - Compassion } \\
\text { - Altruism } \\
\text { - Continuous improvement } \\
\text { - Excellence } \\
\text { - Working in partnership with members of } \\
\text { the wider healthcare team } \\
\text { These values, which underpin the science } \\
\text { and practice of medicine, form the basis for a } \\
\text { moral contract between the medical } \\
\text { profession and society. }\end{array}$ & $\begin{array}{l}\text { - Non-medical } \\
\text { students } \\
\text { - Non-medical } \\
\text { teach- } \\
\text { ers/doctors }\end{array}$ \\
\hline 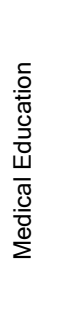 & $\begin{array}{l}\text { Additional components of medical education } \\
\text { focused on to promote professionalism: } \\
\text { - Student selection/admissions to medical } \\
\text { - Schools } \\
\text { - Curriculum design and competency } \\
\text { - Teased curriculum } \\
\text { - Role modelling } \\
\text { - Hidden curriculum } \\
\text { - Assessment }\end{array}$ & \\
\hline 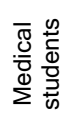 & - Undergraduate medical students & $\begin{array}{l}\text { - Postgraduate } \\
\text { students } \\
\text { - Doctors } \\
\text { - Residents }\end{array}$ \\
\hline $\begin{array}{l}.5 \\
\frac{5}{0} \\
\square\end{array}$ & $\begin{array}{l}\text { - Systematic reviews } \\
\text { - Reviews } \\
\text { - Original research }\end{array}$ & $\begin{array}{l}\text { - Letters } \\
\text { - Editorials }\end{array}$ \\
\hline 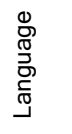 & - English & - Non English \\
\hline 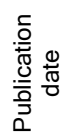 & $\begin{array}{l}\text { - Papers published from } 1998 \text { - October } \\
2008\end{array}$ & $\begin{array}{l}\text { - Papers pub- } \\
\text { lished before } \\
1998\end{array}$ \\
\hline
\end{tabular}


To ensure that all key studies were included we also searched the reference lists of studies identified through the primary search, and conducted a secondary search using themes emerging from studies identified by the primary search. A Reference Manager (version 11) library was created to catalogue these references. The bibliography created from the search produced a list of references with title and/or abstract. The eligibility of each study was assessed jointly by two investigators (VP, MD), based on our inclusion criteria. Studies were included in the review if they were about 'medical professionalism' and included 'undergraduate medical students.' Studies were excluded if they reported professionalism in residents or postgraduate students. We also excluded studies that were not published as full reports, such as conference abstracts/proceedings, letters and editorials. If a clear decision regarding inclusion could not be made from reading the abstract, the full text article was obtained. Our main outcomes were methods used to support and promote the development of professionalism in undergraduate medical students.

\section{Data extraction}

Two assessors independently data extracted full text studies (VP, MD) and the decision to include each paper was made based on the inclusion criteria. The extracted information was systematically collated onto data extraction forms.

\section{Analysis}

We used SPSS version 15 to organise, manage and analyse the search findings. Frequency tables were used to summarise the studies' characteristics. Details of how professionalism is integrated and developed in undergraduate medical students were summarised in detail, although any statistical integration of the data findings was not possible due to the predominantly descriptive nature of the designs. The findings were integrated in a narrative structure.

\section{Results}

The search strategy identified 1332 citations, of which 238 were potentially relevant. After further screening of the 238 titles and/or abstracts, 175 full text articles were obtained following which 41 were excluded as they did not meet the inclusion criteria leaving 134 papers for detailed review (Figure 1).

\section{Focus of included studies}

Five main areas for supporting the development of professionalism in medical students emerged from the analysis of the papers: curriculum design; student selection; teaching and learning methods; role modelling and assessment methods (Table 2). Each of the five areas is described in detail below. These five areas are in accordance with those described by other authors. ${ }^{13,15}$ In all five areas most of the studies are descriptive. The area with the greatest propor- tion of analytical studies is the assessment of professionalism.

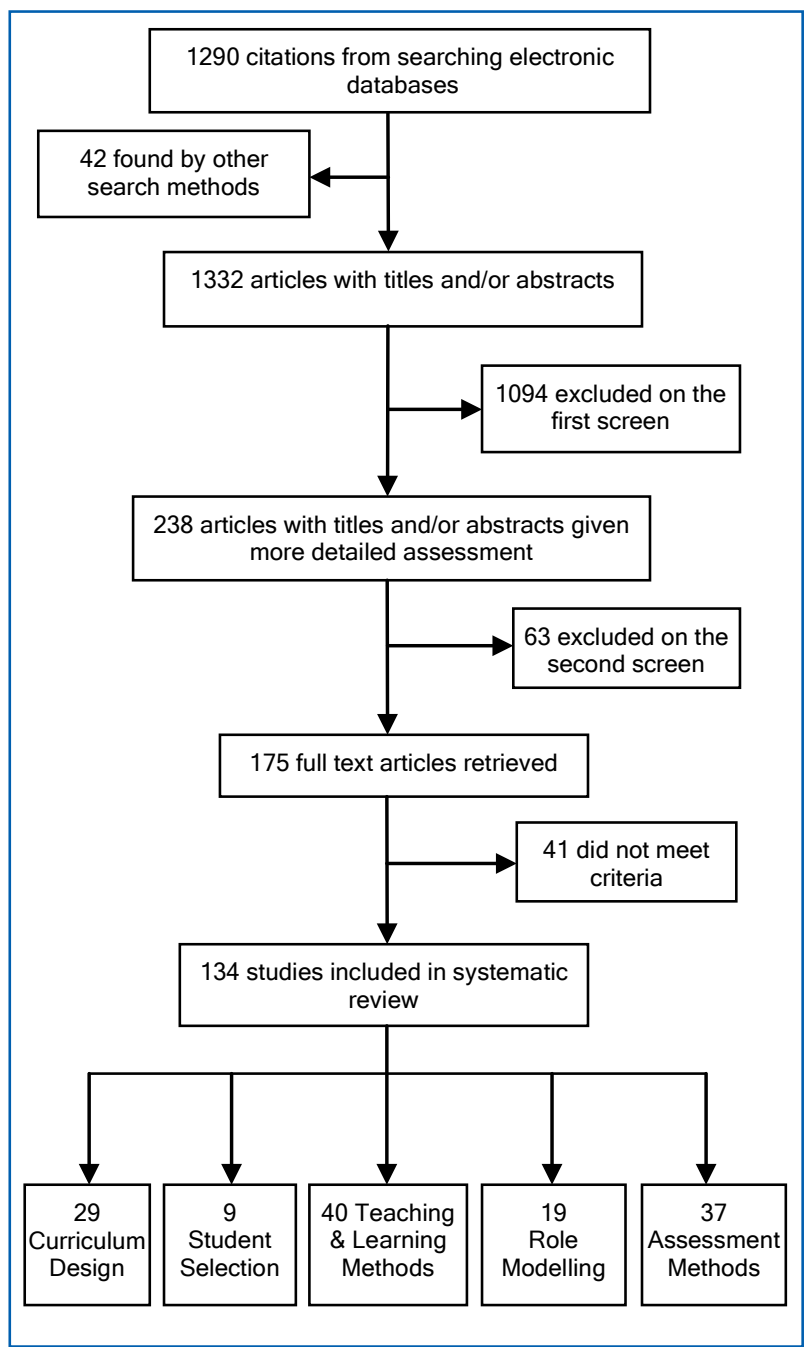

Figure 1. Flow diagram of the search process

\section{Curriculum design}

The systematic review identified 29 papers focusing on curriculum design (see Table 2). Medical schools throughout the world have acknowledged the importance of incorporating professionalism into the undergraduate medical curriculum and there are many descriptions of various curricula that medical schools have designed to integrate professionalism. . $^{18,24-25,29-34,38-39}$

Table 2. Summary of the main focus of articles and associated references identified by the included studies

\begin{tabular}{lc}
\hline Main focus of articles & References \\
\hline Curriculum Design & $2,3,13-39$ \\
Student Selection & $40-48$ \\
Teaching and Learning Methods & $49-87$ \\
Role Modelling & $88-106$ \\
Assessment & $107-143$ \\
\hline
\end{tabular}


However, there is currently no commonly accepted theoretical model being used for the integration of professionalism into the undergraduate curriculum and further analytical research is required to compare the approaches between the different medical schools. The one consistent theme emerging from the literature on curriculum design is that academic institutions must accept greater responsibility and accountability for the professionalism of future doctors. ${ }^{15}$ In the UK, the curriculum must be designed, delivered and assessed to ensure that graduates demonstrate all the outcomes specified in Tomorrow's Doctors. ${ }^{5}$

\section{Student selection}

This systematic review highlighted nine papers focusing on student selection (Table 2). Some medical schools try to avoid selecting students who have unprofessional personal characteristics likely to affect their ability to care for patients and work within a team. ${ }^{40-41}$ There is a correlation between unsatisfactory behaviours on record at medical school and subsequent disciplinary action. ${ }^{42}$ It is argued that to reduce the risk of graduates behaving unprofessionally, potential entrants should be assessed for non cognitive attributes that may be predictive of future professional behaviours in addition to their prior academic achievement. ${ }^{43}$ However, the understanding of which attributes might be predictive remains very limited and ( partly as a consequence) there are as yet no tools with demonstrable validity and reliability for selection on the basis of the likelihood of being able to develop professionalism.

Although there is currently no evidence to support the adoption of any single selection process, a number of models are emerging that have been designed to consider potentially relevant character traits. Examples include the use of the Personal Qualities Assessment tool or the Multiple Mini Interviews (MMI) to test for relevant attributes; the assessment of candidate suitability for a problem based curriculum, a self reported measure of dysfunctional personality characteristics that inhibit the development of working relationships with others and measures of moral orientation prior to the making of a moral decision., ${ }^{70,44-48}$

\section{Teaching and learning methods}

This systematic review found forty papers focusing on teaching and learning methods (Table 2). The papers were mainly descriptive, each describing one method with very little comparison and effective evaluation of the different teaching methods. Table 3 summarises the key teaching methods identified in the literature. Three prominent themes in the teaching and learning of professionalism emerged. Firstly, there was the development of patient centred approaches to care. ${ }^{55,57,80}$ Secondly, there was the focus on encouraging the development of reflective practice. ${ }^{50,52,58,64,67,80-81,83}$ The third was the development of ethical approaches to practice. ${ }^{49,51,53,55,73,81}$ As the teaching of professionalism is highly context dependent and evolution- ary, the teaching and learning methods identified are very helpful in planning varied learning outcomes throughout the undergraduate curriculum. Medical educators may choose to use a variety of methods throughout the curriculum.

Table 3. Teaching and learning methods

\begin{tabular}{lc}
\hline Teaching Method & References \\
\hline Experiential; Reflective Practice & $50,51,53,56,62-$ \\
Clinical Contact including tutor feedback & $64,69,71,77,79,83,86$ \\
& $55-57,65,80$ \\
Undergraduate Ethics Teaching & $49,51,54,55,61-$ \\
& $62,67,73,78,81$ \\
Problem Based Learning & $59,74,76,84,85$ \\
Role Play Exercises & 56,138 \\
Bedside Teaching & $53,63,72,75$ \\
Educational Portfolios & 62,69 \\
Videotaped Consultation Analysis & 52,58 \\
Significant Event Analysis & $58,60,64,83$ \\
Workshops; Interactive Lectures & 50,138 \\
Humanities writing: reading poetry/prose & 85 \\
Related to patient and doctors & \\
Mentoring Programmes & \\
\hline
\end{tabular}

\section{The influence of role modelling}

This systematic review highlighted 19 papers focusing on role modelling as shown in Table 2. Role models are undoubtedly important in professional character formation. ${ }^{88}$ Role modelling is an important method to impart the values of the medical profession, as excellent role models will always encourage professional behaviour in future doctors. ${ }^{89}$ Medical educational programmes should use positive role modelling as an effective teaching tool..$^{90}$

Role modelling takes place in three interrelated educational environments which are the formal, informal and hidden curriculum. The informal curriculum is defined as an 'unspecified, predominantly ad hoc and highly interpersonal form of teaching and learning that takes place among and between faculty and students. ${ }^{91}$ ' The hidden curriculum has been defined as a 'set of influences that function at the level of organisational and culture'..$^{1}$

Institutions need to involve faculty members in an analysis of their educational environment and assist them in adapting their teaching and role modelling. ${ }^{92-97}$ Medical educators need to ensure that learners can understand and reflect on negative role modelling and use it as an effective learning experience. ${ }^{98-100}$ Three characteristics of good role models have recently been described: clinical competence, teaching skills and personal qualities, and this provides a potentially promising framework for the analysis and continuing development of role models. ${ }^{90}$ 


\section{Assessment of professionalism}

This review found 37 papers focusing on the assessment of medical professionalism (Table 2). The different methods of assessment are summarised in Table 4. Several major review articles regarding the assessment of professionalism have recently been published. ${ }^{110,120,124,126,143}$ Arnold, (2002) reviewed over 170 papers and classified assessment instruments into three groups namely those addressing professionalism as part of general clinical competence, those approaching professionalism as a single construct and those addressing separate elements of professionalism such as humanism. ${ }^{110}$ The author concluded that the development of good qualitative methods is needed to strengthen quantitative approaches and that further research is required regarding the environment in which assessment should take place.

Table 4. Methods of assessing medical professionalism

\begin{tabular}{lc}
\hline Assessment Method & References \\
\hline Peer Assessment & $108,109,113,116,120,125,134$, \\
Direct Observation & $113,114,123,128,135$ \\
Patient Evaluations & $113,119,120,126$ \\
Objective Structured Clinical Examination & $113,120,127$ \\
Standardised Patient Assessments & $120,142,139$ \\
Student Evaluation Forms & $122,123,131$ \\
Self Assessment & $113,119,133$ \\
Educational Portfolios & 117,121 \\
Teamwork Exercises & 120,139 \\
Professionalism Mini Evaluation Exercise & 115 \\
P-MEX & 113 \\
Attendance Records & 120 \\
Videotape Analysis & 137 \\
Single Best Answer Multiple Choice & \\
Situational Judgement Test & \\
\hline
\end{tabular}

Epstein and Hundert (2002) reviewed 195 papers, identifying a wide range of assessment tools. ${ }^{120}$ They found that few of the reported assessments observed students in real life situations, incorporated the perspectives of peers and patients or used measures that predict clinical outcomes.

Lynch and colleagues, (2004) reviewed 191 articles published between 1982 and 2002, reporting the use of 88 instruments. ${ }^{126}$ The authors suggested that professionalism assessments may be organised into content area addressed (i.e. ethics, personal characteristics, comprehensive professionalism and diversity) and type of outcome examined (affective, cognitive, behavioural and environmental). The authors concluded that before developing new instruments the existing ones should be improved as many have undergone little testing particularly in terms of their predictive validity.

Veloski and colleagues, (2005) conducted a systematic review of papers published between 1984 and 2002 using a panel of 12 national experts in the USA, and identified a total of 134 empirical studies. ${ }^{143}$ The majority of studies looked at specific components of professionalism (mainly ethical or moral reasoning), with many instruments assessing the learning environment or group behaviour rather than individual behaviour and only a few addressing professionalism as a comprehensive construct. The authors concluded that there were few well documented methods that can be used to measure professionalism formatively or summatively.

Jha et al (2007) performed a systematic review of 97 studies that considered approaches to assessing and facilitating attitudes towards professionalism in medicine. ${ }^{124}$ Whilst recognising that the evidence in this field is limited the authors concluded that there is a need to measure global attitudes rather than attitudes towards specific issues in professionalism and a need to track attitudes throughout the curriculum. The authors demonstrated that there is no single preferred assessment method and also indicated that one reason for this is the lack of a consensus view on exactly what elements of professionalism should be assessed.

In summary, although a large number of instruments have been described, the major studies suggest that there is no single instrument for measuring all aspects of professionalism. ${ }^{110,}{ }^{120,124,126,143}$ Many authors have described the importance of a multidimensional approach with a range of instruments being used throughout the curriculum for both formative and summative assessment purposes. Workplace Based Assessment is thus important, allowing the systematic assessment of professionalism using many different assessors in different clinical settings.

\section{Discussion}

The development of medical professionalism in undergraduate medical education serves an important societal purpose. ${ }^{21}$ To our knowledge, this is the first systematic review to summarise the evidence currently available on methods used by medical schools to promote the development of medical professionalism in their students. The principal strength of this study was the detailed search strategy designed to cover all approaches to the development of professionalism. The clear categorisation of the literature into five main areas will be a useful resource for medical educators, allowing institutions to draw their own conclusions and stimulate further research in the field of medical professionalism.

This review does have some limitations. In particular, whilst we believe that it represents all studies published in this area during the time period concerned, given that professionalism as a concept is still relatively poorly defined we recognise that there is a chance that some keywords may have been missed during the search and thereby some papers not identified, although we believe that this is relatively unlikely given the multifaceted approach taken to the identification of the relevant literature. 
We also recognise limitations imposed by restricting the inclusion solely to studies reported in English; whilst we do not believe that this is likely to have resulted in significant numbers of empirical studies being missed (as the vast majority of empirical studies are published in English), we do recognise that more descriptive papers may have been missed and that this may have excluded alternative constructs of medical professionalism (particularly non Western ones).

This review highlights three main challenges to supporting future doctors to develop their professionalism. Firstly, professionalism is a multifaceted concept and the lack of a consensus definition of professionalism presents a challenge to curriculum design. Secondly, there are no evidence based strategies for the teaching and assessment of professionalism and it will take time to develop and research the main areas identified in this systematic review. Thirdly, individual, societal and political expectations are continually evolving placing increasing demands on doctors. These are big challenges - we hope that this review can precipitate an open debate on the most appropriate approaches to be taken in the development of medical professionalism in future doctors.

\section{Selection}

Selection of students presents a major challenge to medical schools. ${ }^{45}, 48$ There is a requirement to ensure that successful applicants will ultimately be fit to practice which includes their demonstration of professionalism. ${ }^{42}$ However, this review has highlighted the paucity of instruments demonstrated to predict, at the point of selection, students' capacity to develop professionalism. Given the investment involved in undergraduate medical education, further research in this area is required. The literature suggests that perhaps the emphasis should be on de-selection rather than selection - identifying methods that can select out reliably those applicants who are unlikely to be able to develop all aspects of professionalism.

\section{Teaching and learning}

This review highlights the very wide range of approaches that are available for teaching and learning professionalism. However, the very limited comparative data mean that, as yet it is not possible to identify any particular methods demonstrated to be more effective than others. Nevertheless, as professionalism is a complex construct, the evidence suggests the use of a variety of teaching methods throughout the curriculum.

It is clear that the development of professionalism evolves over time by a process of exploration and reflection. Hence, a major objective of medical education should be to provide multiple learning opportunities for gaining experience in and reflecting on the concepts and principles of medical professionalism. We therefore propose that particular emphasis should be placed on learning in the clinical setting, drawing on real day to day examples. Figure 2 demonstrates how this might be done using our 'Professionalism Cycle,' which emphasises the importance of reflection on actions by medical students followed by feedback from the clinical teachers who will also highlight the important principles of professional practice (Figure 2). The documentation of such learning could be presented in an educational portfolio, which documents the development of professional achievements, personal reflections and learning needs throughout the curriculum. ${ }^{117,} 121$ The Professionalism Cycle thus demonstrates the foundations for lifelong learning and continuing professional development that is required by all doctors.

\section{Role modelling}

In medical education, clinical teachers consciously or unconsciously act as role models for students. ${ }^{92,93}$ Doctors who protect time to facilitate feedback, reflection and make a conscious effort to articulate what they are modelling in addition to providing good clinical care are most likely to be recognised as excellent role models. ${ }^{89}$ It is important that medical institutions consider methods to develop the professionalism of staff who act as role models. ${ }^{103-104}$

Personal and professional development of medical students is more likely to occur in a supportive learning environment. Hence, it is important that all medical educators to analyse their learning environments and then develop strategies to ensure that all clinical teachers demonstrate the values, attitudes and behaviours that characterise modern medical professionalism. ${ }^{92}$ The professional attributes associated with effective role models represent behaviours that can be modified and therefore there is a need for medical institutions to support and develop effective doctor role models. ${ }^{93-97}$

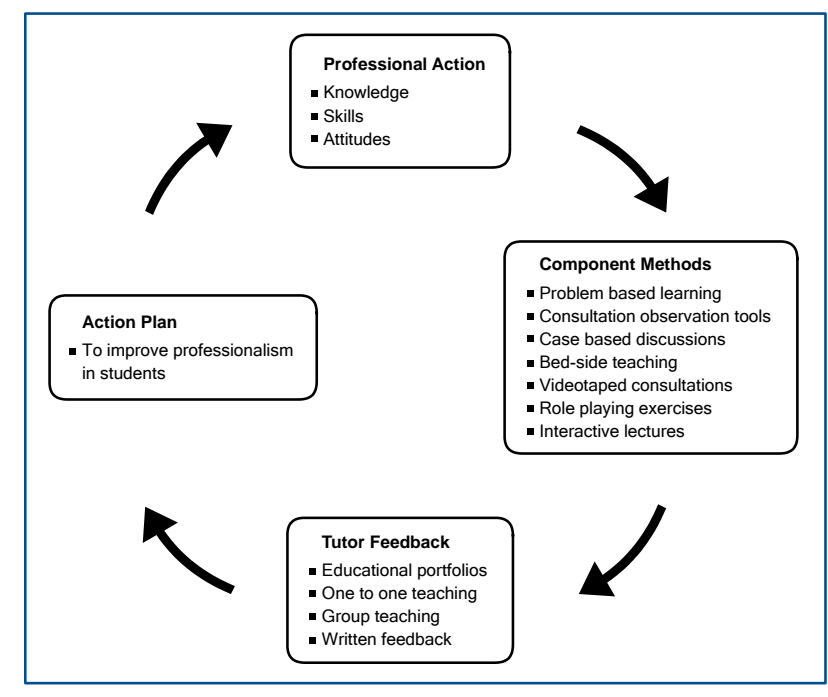

Figure 2. The teaching and learning professionalism cycle

\section{Assessment}

Professionalism is developmental and highly context specific, that is, professional development evolves continu- 
ally throughout the curriculum and its demonstration is highly dependent on the context in which the students find themselves. ${ }^{139}$ The literature emphasises the importance of workplace based assessment methods using different observers marking the medical students' professional performance. The assessment of professionalism should involve both formative and summative methods and this requires faculty input to develop effective clinical assessors. The educational portfolio has been highlighted as a potentially important tool that allows links to be created between the processes of learning and assessment and can assess the more subtle components of professionalism such as integrity, honesty and attitudes. ${ }^{117,}{ }^{121}$ Medical schools internationally could collaborate, as there is a need to develop valid, reliable and practical programmes for the assessment of medical professionalism.

In addition, it is important that medical educators are encouraged to simultaneously address the importance of monitoring of unprofessional or disruptive behaviours. ${ }^{128,131}$ Consideration should be given to developing a framework for understanding approaches to and processes for dealing with unprofessional behaviour. It is important to develop institutional policies to detect unprofessional behaviours and to also develop procedures for the remediation of medical students.

In summary, professionalism in medicine is undoubtedly an extraordinarily complex phenomenon. This review offers a preliminary guide to future discovery and progress in the area of medical professionalism. It is imperative that medical educators worldwide collaborate and share ideas regarding the development of medical professionalism, as we have a duty to ensure that future doctors provide high professional standards of care to our patients.

\section{References}

1. Irvine D. The Doctor's Tale. Oxford: Radcliffe Medical Press; 2003.

2. Hilton SR, Slotnik HB. Proto-professionalism: how professionalization occurs across the continuum of medical education. Med Educ. 2005; 39:58-65.

3. Stephenson A, Higgs R, Sugarman J. Teaching professional development in medical schools. Lancet. 2001;35: 867-870.

4. General Medical Council. Good Medical Practice. London: General Medical Council; 2006.

5. General Medical Council. Tomorrow's Doctors: outcomes and standards for undergraduate medical education. London: General Medical Council; 2009.

6. American Board of Internal Medicine. Project Professionalism. Philadelphia: ABIM; 1995.

7. Thistlethwaite JE, Spencer J. Professionalism in Medicine. Oxford: Radcliffe Medical Press; 2008.

8. Project of ABIM Foundation, ACP-ASIM Foundation and European Federation of Internal Medicine. Medical professionalism in the new millennium: a physician charter. Ann Intern Med. 2002;136:243-6.

9. Royal College of Physicians. Doctors in society: Medical professionalism in a changing world. Report of a Working Party of the RCP. London: Royal College of Physicians; 2005.

10. Martimianakis MA, Maniate JM, Hodges BD. Sociological interpretations of professionalism. Med Educ. 2009;43:829-837.

11. Huddle TS. Teaching professionalism: is medical morality a competency? Acad Med. 2005;80:885-891.

12. Fryer-Edwards K, Eaton EV, Goldstein MD, Kimball HR, Veith RC, Pellegrini CA, Ramsey PG. Overcoming institutional challenges through continuous professionalism improvement: The University of Washington experience. Acad Med. 2007;82:1073-1078.

13. Goldie J. Integrating professionalism teaching into undergraduate medical education in the UK setting. Med Teach. 2008;30:513-527.

14. Archer R, Elder W, Hustedde C, Milam A, Joyce J. The theory of planned behaviour in medical education: A model for integrating professionalism training. Med Educ. 2008;42:771-777.

15. Cohen JJ. Professionalism in medical education, an American perspective: from evidence to accountability. Med Educ. 2006;40:607-617.

16. Barry D, Cyran E, Anderson RJ. Common issues in medical professionalism: room to grow. Am J Med. 2000; 108:136-142.

17. Brainard AH, Brislen HC. Viewpoint: learning professionalism: a view from the trenches. Acad Med. 2007;82: 1010-1014.

18. Brater DC. Viewpoint: infusing professionalism into a school of medicine: perspectives from the dean. Acad Med. 2007;82:1094-1097.

19. Christianson CE, McBride RB, Vari RC, Olsen L, Wilson HD. From traditional to patient-centered learning: Curriculum change as an intervention for changing institutional culture and promoting professionalism in undergraduate medical education. Acad Med. 2007;82:1079-1088.

20. Cohen JJ. Viewpoint: linking professionalism to humanism: what it means and why it matters. Acad Med. 2007;82:1029-1032.

21. Cruess RL, Cruess SR, Johnson SE. Professionalism and medicine's social contract. J Bone Joint Surg Am. 2000;82:1189-1194.

22. Cruess RL, Cruess SR, Johnston SE. Renewing professionalism: an opportunity for medicine. Acad Med. 1999;74:878-884.

23. Cruess SR, Cruess RL. Understanding medical professionalism: a plea for an inclusive and integrated approach. Med Educ. 2008;42:755-757.

24. Humphrey HJ, Smith K, Reddy S, Scott D, Madara JL, Arora VM. Promoting an environment of professionalism: 
the University of Chicago Roadmap. Acad Med. 2007;82:1098-1107.

25. Hilgers J, De Roos P, Rigby E. European core curriculum- the students' perspective, Bristol, UK, 10 July 2006. Med Teach. 2007;29:270-275.

26. Jha V, Becker HL, Duffy SG, Roberts TE. Perceptions of professionalism in medicine: a qualitative study. Med Educ. 2006;40:1027-1036.

27. Kinghorn WA, McEvoy MD, Michel A, Balboni M. Professionalism in modern medicine: does the emperor have any clothes. Acad Med. 2007;82: 40-45.

28. Mann KV, Ruedy J, Millar N, Andreou P. Achievement of non cognitive goals of undergraduate medical education: perceptions of medical students, residents, faculty and other health professionals. Med Educ. 2005;39:40-48.

29. Parker M, Luke H, Zhang J, Wilkinson D, Peterson R, Ozolins I. The pyramid of professionalism: seven years of experience with an integrated program of teaching, developing and assessing professionalism among medical students. Acad Med. 2008;83:733-741.

30. Shrank WH, Reed VA, Jernstedt GC. Fostering professionalism in medical education: a call for improved assessment and meaningful incentives. J Gen Int Med. 2004; 19: 887-892.

31. Sivalingam N. Teaching and learning of professionalism in medical schools. Ann Acad Med Singapore. 2004;33:706710 .

32. Smith KL, Saavedra R, Raeke JL, O'Donell A. The journey to creating a campus-wide culture of professionalism. Acad Med. 2007;82:1015-1021.

33. Steinert Y, Cruess RL, Cruess SR, Boudreau JD, Fuks A. Faculty development as an instrument of change: a case study on teaching professionalism. Acad Med. 2007;82:1057-1064.

34. Stewart RW, Barker AR, Shochet RB, Wright SM. The new and improved learning community at Johns Hopkins University School of Medicine resembles that at Hogwarts School of Witchcraft and Wizardry. Med Teach. 2007;29:353-357.

35. Swick HM. Professionalism: a key to weathering the storm. Obstet \& Gynecol. 2001;98:156-161.

36. Swick HM. Toward a normative definition of medical professionalism. Acad Med. 2000;75:612-616.

37. Tsai TC, Lin CH, Harasym PH, Violato C. Students' perception on medical professionalism: The psychometric perspective. Med Teach. 2007;29:128-134.

38. Wasserstein AG, Brennan PJ, Rubenstein AH. Institutional leadership and faculty response: fostering professionalism at the University of Pennsylvania School Of Medicine. Acad Med. 2007;82:1049-1056.

39. Wear D, Castellani B. The development of professionalism: Curriculum Matters. Acad Med. 2000;75:602-11. 40. Albanese MA, Snow MH, Skochelak SE, Huggett KN,
Farrell PM. Assessing personal qualities in medical school admissions. Acad Med. 2003;78:313-321.

41. Bore M, Munro D, Kerridge I, Powis D. Selection of medical students according to their moral orientation. Med Edu. 2005;39:266-275.

42. Chamberlain SE, Searle J. Assessing suitability for a problem-based learning curriculum: evaluating a new student selection instrument. Med Educ. 2005;39:250-257. 43. Knights JA, Kennedy BJ. Medical school selection: Screening for dysfunctional tendencies. Med Educ. 2006;40:1058-1064.

44. Lumsden MA, Bore M, Millar K, Jack R, Powis D. Assessment of personal qualities in relation to admission to medical school. Med Educ. 2005;39:258-265.

45. Morrison J. How to choose tomorrow's doctors. Med Educ. 2005;39:240-242.

46. Morrison J. Professional behaviour in medical students and fitness to practice. Med Educ. 2008;42:118-120.

47. Papadakis MA, Teherani A, Banach MA, Knettler TR, Rattner SL, Stern DT et al. Disciplinary action by medical boards and prior behavior in medical school. N Engl J Med. 2005;353:2673-2682.

48. Parry J, Mathers J, Stevens A, Parsons A, Lilford R, Spurgeon $\mathrm{P}$ et al. Admissions processes for five year medical courses at English schools. BMJ. 2006;332:1005-1009.

49. Andre J, Brody H, Fleck L, Thomason CL, Tomlinson T. Ethics, professionalism, and humanities at Michigan State University College of Human Medicine. Acad Med. 2003:10: 968-972.

50. Baernstein A, Fryer-Edwards K. Promoting reflection on professionalism: a comparison trial of educational interventions for medical students. Acad Med. 2003;78:742747.

51. Benbassat J, Baumal R. What is empathy, and how can it be promoted during clinical clerkships? Acad Med. 2004; 79:832-839.

52. Ber R, Alroy G. Teaching professionalism with the aid of trigger films. Med Teach. 2002;24:528-531.

53. Branch WT. Teaching Respect for Patients. Acad Med. 2006;81:463-467.

54. Buyx AM, Maxwell B, Schone-Seifert B. Challenges of educating for medical professionalism: who should step up to the line? Med Educ. 2008;42:758-764.

55. Cordingley L, Hyde C, Peters S, Vernon B, Bundy C. Undergraduate medical students' exposure to clinical ethics: A challenge to the development of professional behaviours? Med Educ. 2007;41:1202-1209.

56. Duff P. Teaching and assessing professionalism in medicine. Obstet Gynecol. 2004;104:1362-1366.

57. Fishbein RH. Professionalism and 'the master clinician'-an early learning experience. J Eval Clin Pract. 2000;6:241243.

58. Ginsburg S, Regehr G, Lingard L. The disavowed 
curriculum: understanding student's reasoning in professionally challenging situations. J Gen Intern Med. 2003;18:1015-1022.

59. Goldie J, Dowie A, Cotton P, Morrison J. Teaching professionalism in the early years of a medical curriculum: a qualitative study. Med Educ. 2007;41:610-617.

60. Goldie J, Schwartz L, McConnachie A, Morrison J. Students' attitudes and potential behaviour with regard to whistle blowing as they pass through a modern medical curriculum. Med Educ. 2003;37:368-375.

61. Goldie J, Schwartz L, McConnachie A, Morrison J. The impact of a modern medical curriculum on students' proposed behaviour on meeting ethical dilemmas. Med Educ. 2004;38:942-949.

62. Gordon J. Fostering students' personal and professional development in medicine: a new framework for PPD. Med Educ. 2003;37:341-349.

63. Hatem CJ. Teaching approaches that reflect and promote professionalism. Acad Med. 2003;78:709-13.

64. Henderson E, Berlin A, Freeman G, Fuller J. Twelve tips for promoting significant event analysis to enhance reflection in undergraduate medical students. Med Teach. 2002;2:121-123.

65. Hesketh EA, Bagnall G, Buckley EG, Friedman M, Goodall E, Harden RM et al. A framework for developing excellence as a clinical educator. Med Educ. 2001;35:555564.

66. Hickson GB, Pichert JW, Webb LE, Gabbe SG. A complementary approach to promoting professionalism: identifying, measuring, and addressing unprofessional behaviors. Acad Med. 2007;82:1040-1048.

67. Hilton S, Southgate L. Professionalism in medical education. Teaching and Teacher Education. 2007;23: 265279.

68. Howe A. Professional development in undergraduate medical curricula--the key to the door of a new culture? Med Educ. 2002;36:353-359.

69. Kalet AL, Sanger J, Chase J, Keller A, Schwartz MD, Fishman ML et al. Promoting professionalism through an online professional development portfolio: successes, joys, and frustrations. Acad Med. 2007;82:1065-1072.

70. Kao A, Lim M, Spevick J, Barzansky B. Teaching and evaluating students' professionalism in US medical schools, 2002-2003. JAMA. 2003;290:1151-1152.

71. Kenyon CF, Brown JB. Mission statement day: the impact on medical students of an early exercise in professionalism. Med Teach. 2007;29:606-610.

72. Martin J, Lloyd M, Singh S. Professional attitudes: can they be taught and assessed in medical education? Clin Med. 2002;2:217-223.

73. Mattick K, Bligh J. Undergraduate ethics teaching: revisiting the Consensus Statement. Med Educ. 2006; 4:329332.
74. Causley G, Williams EMI, Taylor DCM. Junior medical students' notions of a 'good doctor' and related expectations: a mixed methods study. Med Educ. 2007;41:476-486.

75. Mel KA. What is happening to bedside clinical teaching? Med Educ. 2002;36:1185-1188.

76. Norman GR, Wenghofer E, Klass D. Predicting doctor performance outcomes of curriculum interventions: problem-based learning and continuing competence. Med Educ. 2008;42:794-799.

77. Preez RR, Pickworth GE, Van RM. Teaching professionalism: a South African perspective. Med Teach.2007;e284291.

78. Robins LS, Braddock CH, Fryer-Edwards KA. Using the American Board of Internal Medicine's "elements of professionalism" for undergraduate ethics education. Acad Med. 2002;6:523-531.

79. Rucker L, Shapiro J. Becoming a physician: students' creative projects in a third-year IM clerkship. Acad Med. 2003;78:391-397.

80. Scavenius M, Schmidt S, Klazinga N. Genesis of the professional-patient relationship in early practical experience: qualitative and quantitative study. Med Educ. 2006;10:1037-1044.

81. Shapiro J, Morrison E, Boker J. Teaching empathy to first year medical students: evaluation of an elective literature and medicine course. Educ Health. 2004;17:73-84.

82. Spencer J. Teaching about professionalism. Med Educ. 2003;37:288-289.

83. Stark P, Roberts C, Newble D, Bax N. Discovering professionalism through guided reflection. Med Teach. 2006;28:e25-31.

84. Stark P. Teaching and learning in the clinical setting: a qualitative study of the perceptions of students and teachers. Med Educ. 2003;11:975-982.

85. Stephenson AE, Adshead LE, Higgs RH. The teaching of professional attitudes within UK medical schools: Reported difficulties and good practice. Med Educ. 2006;11:10721080.

86. Swick HM, Szenas P, Danoff D, Whitcomb ME. Teaching professionalism in undergraduate medical education. JAMA. 1999;282:830-832.

87. Woloschuk W, Harasym PH, Temple W. Attitude change during medical school: A cohort study. Med Educ. 2004;38: 522-534.

88. Kenny NP, Mann KV, MacLeod H. Role modeling in physicians' professional formation: reconsidering an essen tial but untapped educational strategy. Acad Med. 2003;78:1203-1210.

89. Wright SM, Kern DE, Kolodner K, Howard DM, Brancati FL. Attributes of excellent attending-physician role models. New Eng J Med. 1998;339:1986-1993.

90. Cruess SR, Cruess RL, Steinert Y. Role modellingmaking the most of a powerful teaching strategy. BMJ. 2008; 336:718-721. 
91. Hafferty FW. Beyond curriculum reform: confronting medicine's hidden curriculum. Acad Med. 1998;73:403-07. 92. Paice E, Heard S, Moss F. How important are role models in making good doctors? BMJ. 2002;325:707-710.

93. Weissmann PF, Branch WT, Gracey CF, Haidet P, Frankel RM. Role modeling humanistic behavior: learning bedside manner from the experts. Acad Med. 2006;81: 661667.

94. Sutkin G, Wagner E, Harris I, Schiffer R. What makes a good clinical teacher in medicine? A review of the literature. Acad Med. 2008;83:452-466.

95. Wright SM, Carrese JA. Serving as a physician role model for a diverse population of medical learners. Acad Med. 2003;78:623-628.

96. Yazigi A, Nasr M, Sleilaty G, Nemr E. Clinical teachers as role models: perceptions of interns and residents in a Lebanese medical school. Med Educ. 2006;40:654-661.

97. Wright S, Wong A, Newill C. The impact of role models on medical students. J Gen Int Med.1997;12:53-56.

98. D'Eon M, Lear N, Turner M, Jones C. Perils of the hidden curriculum revisited. Med Teach. 2007;29:295-296.

99. Glicken AD, Merenstein GB. Addressing the hidden curriculum: understanding educator professionalism. Med Teach. 2007;29:54-57.

100. Hafferty FW, Franks R. The hidden curriculum, ethics teaching, and the structure of medical education. Acad Med. 1994;69:861-871.

101. Swick HM. Viewpoint: Professionalism and humanism beyond the academic health center. Acad Med. 2007;82:1022-1028.

102. Hafferty FW. What medical students know about professionalism. Mt Sinai J Med 2002; 69:385-397.

103. Jones WS, Hanson JL, Longacre JL. An intentional modeling process to teach professional behavior: students' clinical observations of preceptors. Teach Learn Med. 2004;16:264-269.

104. Kahn MW. Etiquette-based medicine. NEJM. 2008; 358:1988-1989.

105. Lempp H, Seale C. The hidden curriculum in undergraduate medical education: qualitative study of medical students' perceptions of teaching. BMJ. 2004;7469:770-773.

106. Lindemann J, Soule D. Teaching professionalism to medical students: a faculty guide. The Journal of the South Dakota State Medical Association. 2006;59:203-205.

107. Arnold EL, Blank LL, Race KE, Cipparrone N. Can professionalism be measured? The development of a scale for use in the medical environment. Acad Med. 1998;73:1119-1121.

108. Arnold L, Shue CK, Kalishman S, Prislin M, Pohl C, Pohl $\mathrm{H}$ et al. Can there be a single system for peer assess ment of professionalism among medical students? A multiinstitutional study. Acad Med. 2007;82:578-586.

109. Arnold L, Shue CK, Kritt B, Ginsburg S, Stern DT.
Medical students' views on peer assessment of professional ism. J Gen Intern Med. 2005;20:819-824.

110. Arnold L. Assessing professional behavior: yesterday, today, and tomorrow. Acad Med. 2002;77:502-515.

111. Blackall GF, Melnick SA, Shoop GH, George J, Lerner SM, Wilson PK et al. Professionalism in medical education: the development and validation of a survey instrument to assess attitudes toward professionalism. Med Teach. 2007;29:e58-62.

112. Bonke B. Unprofessional or problematic behaviour of medical students outside the learning environment. Med Teach. 2006;28:440-442.

113. Boon K, Turner J. Ethical and professional conduct of medical students: review of current assessment measures and controversies. J Med Ethics 2004;30:221-226.

114. Cohen R. Assessing professional behaviour and medical error. Med Teach. 2001;23:145-151.

115. Cruess R, Cruess S, Ginsburg S, Steinert Y. The professionalism mini-evaluation exercise: a preliminary investigation. Acad Med. 2006;81:S74-S78.

116. Dannefer EF, Henson LC, Bierer SB, Grady-Weliky TA, Meldrum S, Nofziger AC et al. Peer assessment of professional competence. Med Educ. 2005;39:713-722.

117. Driessen E, van Tartwijk J, van der Vleuten C, Wass V. Portfolios in medical education: why do they meet with mixed success? A systematic review. Med Educ. 2007; 41:1224-1233.

118. Elcin M, Odabasi O, Gokler B, Sayek I, Akova M, Kiper N. Developing and evaluating professionalism. Med Teach. 2006;28:36-39.

119. Epstein RM, Dannefer EF, Nofziger AC, Hansen JT, Schultz SH, Jospe $\mathrm{N}$ et al. Comprehensive assessment of professional competence: the Rochester experiment. Teach Learn Med. 2004;16:186-196.

120. Epstein RM, Hundert EM. Defining and assessing professional competence. JAMA. 2002;287:226-235.

121. Friedman Ben David M, Davis MH, Harden RM, Howie PW, Ker J, Pippard MJ. AMEE Medical Education Guide No. 24: Portfolios as a method of student assessment. Med Teach. 2001;23:535-551.

122. Frohna A, Stern D. The nature of qualitative comments in evaluating professionalism. Med Educ. 2005;39:763-768.

123. Hemmer PA, Hawkins R, Jackson JL, Pangaro LN. Assessing how well three evaluation methods detect deficiencies in medical students' professionalism in two settings of an internal medicine clerkship. Acad Med. 2000;75:167173.

124. Jha V, Bekker HL, Duffy SRG, Roberts TE. A systematic review of studies assessing and facilitating attitudes towards professionalism in medicine. Med Educ. 2007;41: 822-829.

125. Lurie SJ, Nofziger AC, Meldrum S, Mooney C, Epstein RM. Effects of rater selection on peer assessment among 
medical students. Med Educ. 2006;40:1088-1097.

126. Lynch DC, Surdyk PM, Eiser AR. Assessing professionalism: a review of the literature. Med Teach. 2004;26:366-373.

127. Mazor KM, Zanetti ML, Alper EJ, Hatem D, Barrett $\mathrm{SV}$, Meterko $\mathrm{V}$ et al. Assessing professionalism in the context of an objective structured clinical examination: An in-depth study of the rating process. Med Educ. 2007;41:331-340.

128. Murden RA, Way DP, Hudson A, Westman JA. Professionalism deficiencies in a first-quarter doctor-patient relationship course predict poor clinical performance in medical school. Acad Med. 2004;79: S8.

129. Murdoch-Eaton DG, Levene MI. Formal appraisal of undergraduate medical students: is it worth the effort? Med Teach. 2004;1:28-32.

130. O'Sullivan AJ, Toohey S. Assessment of professionalism in undergraduate medical students. Med Teach. 2008;3:280-286.

131. Papadakis MA, Loeser H, Healy K. Early detection and evaluation of professionalism deficiencies in medical students: one school's approach. Acad Med. 2001;76:110006.

132. Parker M. Assessing professionalism: Theory and practice. Med Teach. 2006;28:399-403.

133. Rees C, Shepherd M. Students' and assessors' attitudes towards students' self-assessment of their personal and professional behaviours. Med Educ. 2005;39:30-39.

134. Rees C, Shepherd M. The acceptability of 360-degree judgments as a method of assessing undergraduate medical students' personal and professional behaviours. Med Educ. 2005;39: 49-57.
135. Rees CE, Knight LV. The trouble with assessing students' professionalism: theoretical insights from sociocognitive psychology. Acad Med. 2007;82: 46-50.

136. Schonrock-Adema J, Heijne -Penninga M, Geertsma J, Cohen-Schotanus J. Assessment of professional behaviour in undergraduate medical education: peer assessment enhances performance. Med Educ. 2007;41:836-842.

137. Schubert S, Ortwin H, Dumitsch A, Schwantes U, Wilhelm O, Kiessling C. A situational judgement test of professional behaviour: development and validation. Med Teach. 2008;30:528-533.

138. Steinert Y, Cruess S, Cruess R, Snell L. Faculty development for teaching and evaluating professionalism: from programme design to curriculum change. Med Educ. 2005;39:127-136.

139. Stern D. Measuring Medical Professionalism. New York: Oxford University Press; 2004.

140. Stern D, Frona A, Gruppen L. The prediction of professional behaviour. Med Educ. 2005;39:75-82.

141. Van Mook W, De Grave W, Huijssen-Huisman E, De Witt-Luth M, Dolmans D, Muijtjens AM et al. Factors inhibiting assessment of students' professional behaviour in the tutorial group during problem based learning. Med Educ. 2007;9:849-856.

142. Van Zanten M, Boulet JR, Norcini JJ, McKinley D. Using standardised patient assessment to measure professional attributes. Med Educ. 2005;39: 20-29.

143. Veloski JJ, Fields SK, Boex JR, Blank LL. Measuring professionalism: a review of studies with instruments reported in the literature between 1982 and 2002. Acad Med. 2005;80:366-370. 